\title{
Distributed parameter arterial tree modeling using D mode ultrasound images
}

\author{
I. Kupčiūnas, A. Kopustinskas
}

\author{
Department of electrical and Control Equipment, \\ Studentu 50, 51368 Kaunas, LITHUANIA, Phone: +370 37 351162,E-mail: irmantas_k@yahoo.com.
}

\begin{abstract}
Distributed parameter arterial tree model, based on transmission line theory is proposed. Adequacy of the model is confirmed using noninvasive "in vivo" ultrasound Doppler images. Ultrasound measurements in three characteristic locations of human arterial tree are performed. Comprised model enables to acquire typical blood flow time functions in 40 arteries. Parameters of the model are related to relevant geometrical and mechanical arteries properties. The model can be used in the research into the influence of blood vessel mechanical parameters on the form of flow time function as well as when estimating possibilities of diagnostics of blood flow system lesion.

Keywords: artery, model, index, ultrasound, image.
\end{abstract}

\section{Introduction}

Due to it's vital role human blood circulation has been investigated and modeled by many researches. Various models, including those based on calculation of NavierStokes equations [1] and finite element method [2], has been proposed in past decade. These methods are relatively precise, i.e. they evaluate complex and often non-linear effects of blood circulation. They require significant computational efforts and usually are employed only for small blood-vessel segments: stenosis, bifurcation sites. A little simpler approach - electric or electrohemodynamic analogy models. From this group widely used are two, three or even four element Windkessel models [3]. They give lumped representation of a heart-circulatory system and can help to understand how the arterial system functions, can be used as a realistic load in isolated heart studies and can form the basis for the estimating arterial system parameters. However, it's important to note, that pulse wave transmission doesn't exist in Windkessel type models. Distributed parameters models can be also identified belonging to electric analogy group. Distributed models [4] account for the geometry, oscillatory flow theory and viscoelastic properties of the arterial wall. They allow the study of wave travel, reflections, the understanding of pressures and flows at different locations in the arterial tree.

In the modelling of blood circulation, an important task is the diagnostics of damage to arteries. Such pathologic blood vessel lesion as the reduction of elasticity properties, change of wall width, emergence of formations of stenosic nature, etc. generally relate to mechanic properties of blood vessels and parameters of blood flow. Awareness of this allows deciding about the progress and degree of lesion.

Adequacy validation is essential element for the blood circulation modelling. Nonivasive "in vivo" methods and techniques are desirable to employ the model for the routine medical diagnostic. Ultrasound imagining is universal, reliable and cost-effective technique. D mode ultrasound has been widely accepted diagnostic tool for over forty years and allows not only to measure blood flow velocity, but also to asses important parameters of the circulation, i.e. pulsatility index, resistive index, systolic-diastolic ratio and etc.

The purpose of this work is to propose human distributed arterial tree model, which adequacy can be validated using "in vivo" noninvasive ultrasound images, intended to investigate the possibility to evaluate artery mechanical properties.

\section{Method}

The major assumptions for the proposed model:

- Hooke's law applies to artery wall, i.e. modulus of elasticity (E) is not affected by blood pressure;

- Flow resistance (R), compliance (C) and inertance (L) are constant, i.e. not affected by blood pressure and flow in artery segment;

- Blood is Newtonian, i.e., viscosity is constant.

The basic idea of the distributed model is to break up the arterial tree into small segments whose geometry and mechanical properties are known. Furthermore each segment can be represented using transmission line theory (Fig. 1).

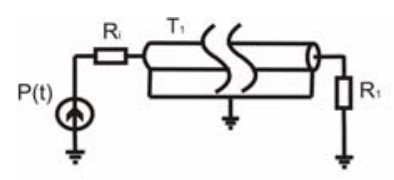

A

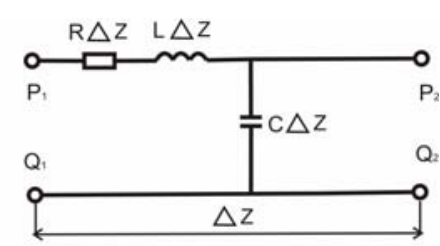

B
Fig. 1. Transmission line representation of artery segment (A) and $\Delta z$ length section of a transmission line (B)

For the small $\Delta \mathrm{z}$ section the constitutive equations are:

$$
\begin{aligned}
& -\frac{\partial P}{\partial z}=\left(R^{\prime}+j \omega L^{\prime}\right) \cdot Q, \\
& -\frac{\partial Q}{\partial z}=j \omega C \cdot P,
\end{aligned}
$$


where $P$ - blood pressure; $Q$ - blood flow; $R, C, L$ - artery resistance, capacitance and conductance; $z$ - artery segment lenght; $\omega=2 \pi f$ angular heart frequency; $f$ - frequency.

Heart and aortic valve correspond to a voltage source, which signal dynamics match typical blood pressure change over time, meassured below the aortic valve, i.e. in the origin of the ascending aorta (Fig. 2). Signal period is $0.8 \mathrm{~s}$ and $1 \mathrm{~V}$ represents $100 \mathrm{mmHg}$.

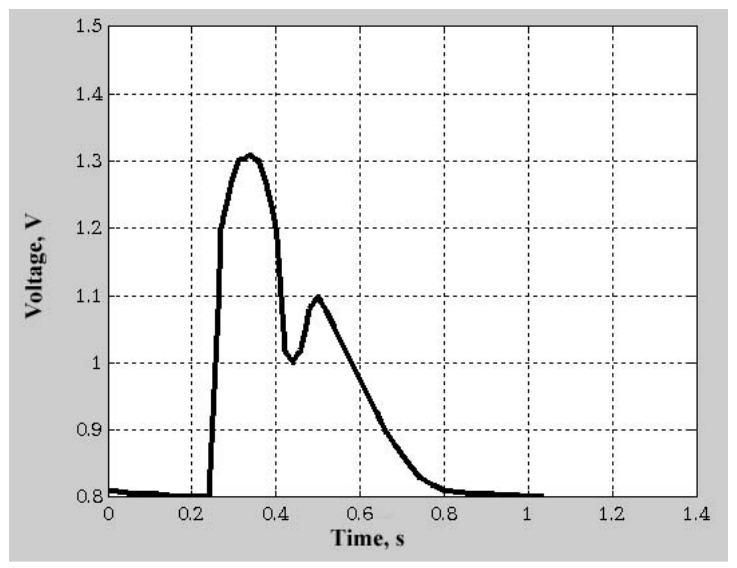

Fig. 2. Dynamics of the voltage source signal

Arterial tree model is shown in Fig. 4. It is comprised of 40 main artery tree segments, each of which is represented by the corresponding transmission line (Fig. 1). Properties of some arteries are presented in Table 1 [5].

The Poiseuille's law shows that artery resistance depends on the length $l$, radius $r$ of the vessel and viscosity $\eta$ of blood:

$$
R=\frac{8 \cdot \eta \cdot l}{\pi \cdot r^{4}} .
$$

It's assumed, that every artery wall is straight and uniform in the whole length, blood flow is laminar and crosssectional blood velocity profile is parabolic.

Artery area compliance $C_{A}$ is related to the elastic modulus $E$ by the following expression:

$$
C_{A}=\frac{2 \cdot \pi \cdot r^{3}}{E \cdot h},
$$

where $h$-artery wall thickness.

Artery inertance can be derived from the Newton's equation:

$$
L=\rho \cdot \frac{l}{A},
$$

where $\rho$-blood density.

Using above equations, corresponding properties for the transmission lines are evaluated (Table 1).
All the above parameters are adjusted to reflect the influence of the smallest arteries, which were not included in the arterial tree model. ORCAD programming package was employed for the modeling of arterial tree. Constant current mode is applied for the modeling.

Table 1. Arteries properties and transmission line parameters

\begin{tabular}{|l|l|l|l|l|l|l|l|}
\hline \multirow{2}{*}{$\begin{array}{l}\text { Artery } \\
\text { name }\end{array}$} & \multicolumn{3}{|l|}{$\begin{array}{l}\text { Artery properties (1-length, } \\
\mathrm{r} \text { - radius, } \mathrm{h}-\text { wall thickness, } \mathrm{C}_{\mathrm{A}} \\
- \text { area compliance) }\end{array}$} & \multicolumn{2}{l}{\begin{tabular}{l}
\multicolumn{2}{l}{ Transmission line } \\
parameters
\end{tabular}} \\
\cline { 2 - 8 } & $1, \mathrm{~m}$ & $\mathrm{r}, \mathrm{m}$ & $\mathrm{h}, \mathrm{m}$ & $\begin{array}{l}\mathrm{C}_{\mathrm{A}}, \\
\mathrm{N} / \mathrm{m}^{2} \\
10^{4}\end{array}$ & $\begin{array}{l}\mathrm{R}, \\
\Omega / \mathrm{m}\end{array}$ & $\mathrm{L}, \mathrm{H} / \mathrm{m}$ & $\begin{array}{l}\mathrm{C}, \\
\mathrm{F} / \mathrm{m}\end{array}$ \\
\hline $\begin{array}{l}\text { Abdomina } \\
\text { l aorta }\end{array}$ & 0,15 & 0,0185 & 0,0009 & 95 & 54,6 & 21,7 & 2 \\
\hline $\begin{array}{l}\text { Common } \\
\text { carotid }\end{array}$ & 0,18 & 0,009 & 0,0008 & 55 & 42,3 & 40,6 & 2,4 \\
\hline Brachial & 0,2 & 0,006 & 0,0005 & 250 & 112,7 & 32,4 & 1,1 \\
\hline Femoral & 0,32 & 0,008 & 0,0005 & 260 & 121,4 & 38 & 1,5 \\
\hline $\begin{array}{l}\text { Anterior } \\
\text { tibial }\end{array}$ & 0,4 & 0,003 & 0,0003 & 600 & 167,2 & 16,8 & 0,6 \\
\hline
\end{tabular}

Ultrasound Doppler system is used to acquire D mode images from various human arteries (Fig. 3). We can calculate mean blood flow $Q_{\text {mean }}$, which is related to corresponding mean velocity $V_{\text {mean }}$ :

$$
Q_{\text {mean }}=A \cdot V_{\text {mean }} \text {. }
$$

Fig. 5 shows mean blood flow calculated in common carotid artery. All image processing are performed using MATLAB programming package.

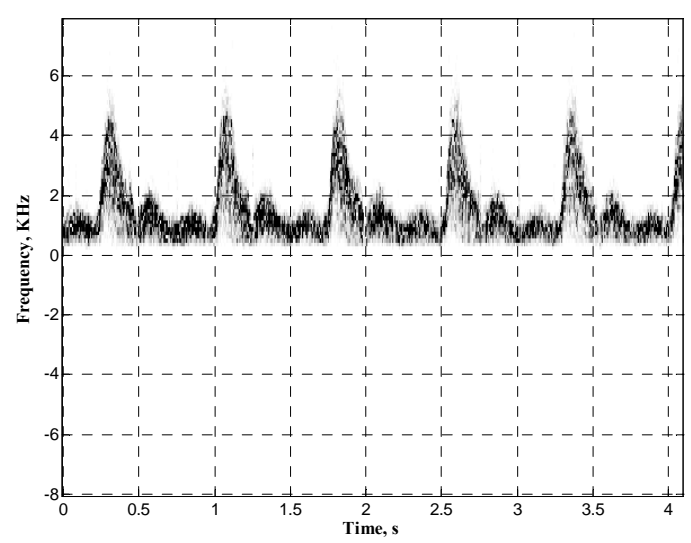

Fig. 3. Common carotid artery $D$ mode ultrasound image 
ISSN 1392-2114 ULTRAGARSAS (ULTRASOUND), Vol. 66. No. 2. 2011.

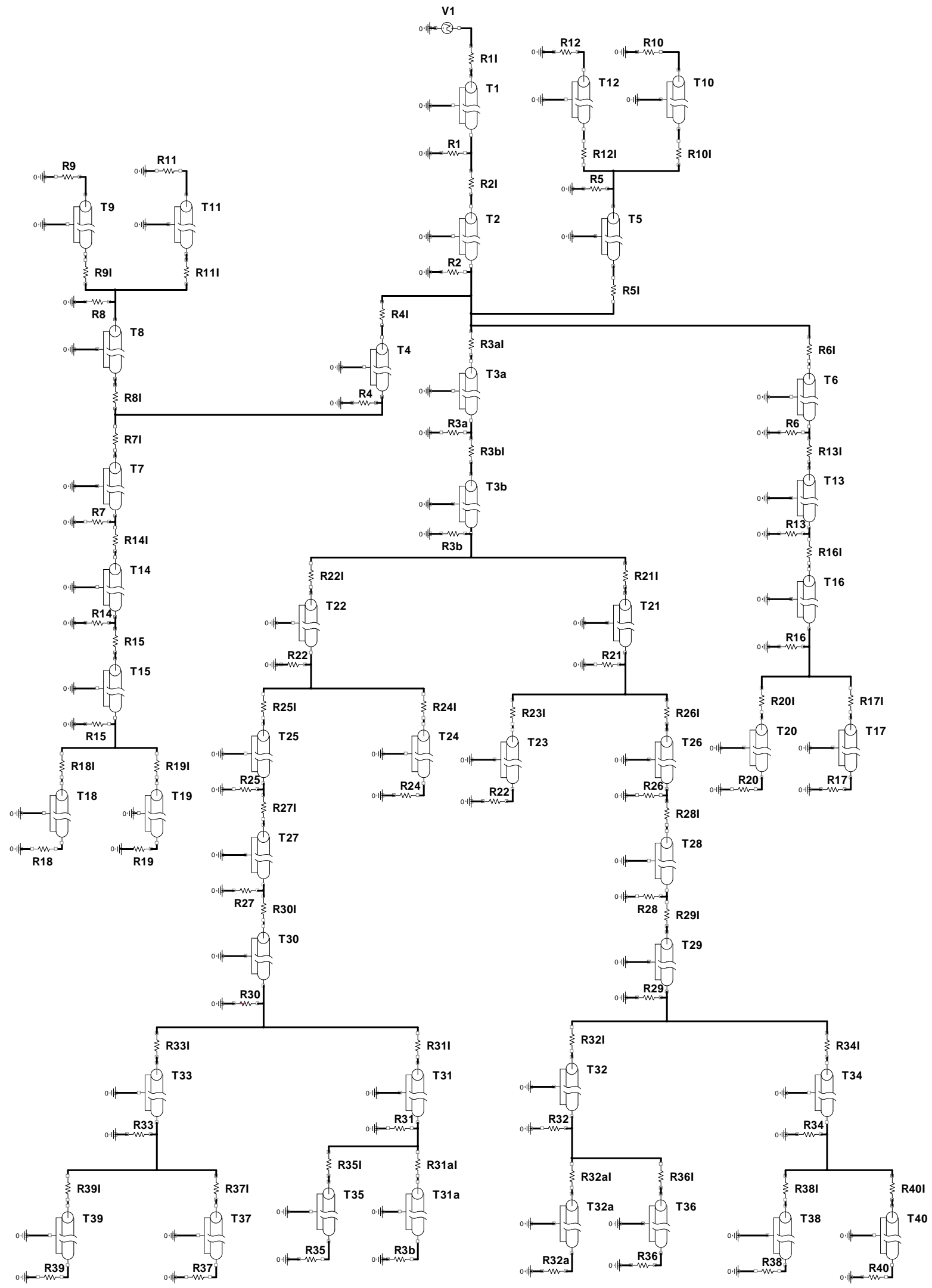

Fig. 4. Schematic representation of the arterial tree model 


\section{Results}

Ultrasound measurements were performed with Ultrasonic Blood Flow Detector UDD-03, developed in the medical electronic laboratory [7]. It allows acquiring Doppler signal time function primary data in real time.

Measurements were performed "in vivo" in three characteristic locations of a volunteer - left common carotid (carotis communis sinistra), left brachial (brachialis sinistra) and left ulnar (ulinaris sinistra) arteries. For each artery measurement was repeated 12 times. To evaluate adequacy of the proposed tree model, "in vivo" measured blood flow functions were compare to corresponding functions acquired during modeling (Figs. 5 and 6).

Relevant circulation indices, i.e. pulsatility (PI), resistive (RI) indices and systolic-diastolic ratio (S/D), were calculated both for measured, and for modeled blood flow (Table 2). Mean standard deviation: PI - 18\%, RI - 3\%, S/D $-6 \%$.

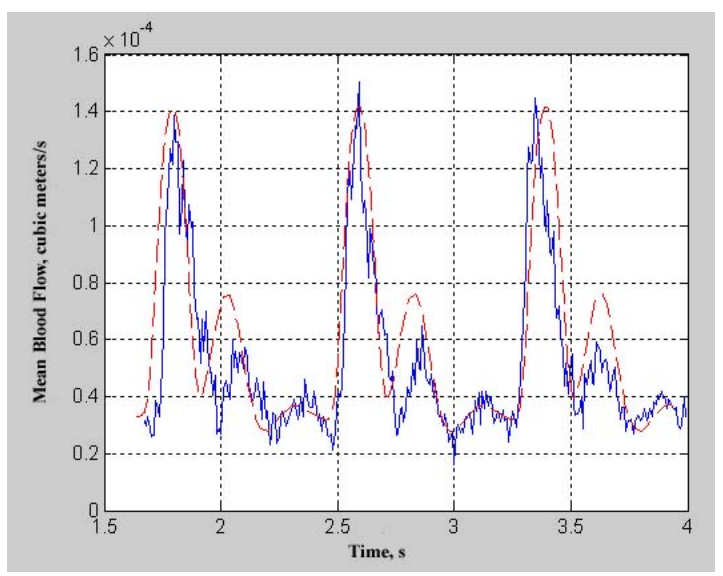

Fig. 5. Modeled (continuous) and measured (dashed) mean blood flow time functions for the left common carotid artery

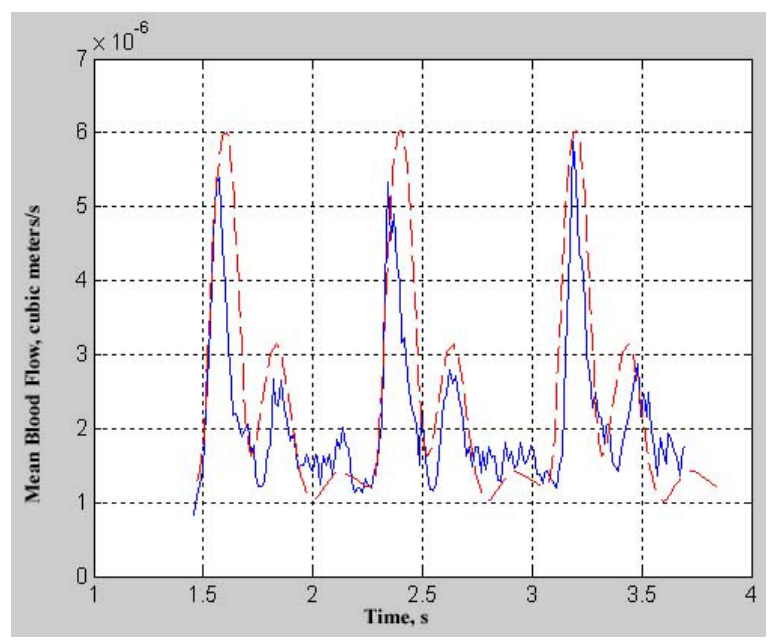

Fig. 6. Modeled (continuous) and measured (dashed) mean blood flow time functions for the left ulnar artery
Relationships between blood circulation indices and relevant mechanical parameter - elastic modulus - were modeled (Figs. 7 and 8). Modulus values were increased and decreased for the whole artery tree and PI, RI where calculated, respectively. Character of the modeled relationships of all investigated arteries is similar.

Table 2. Measured and modeled circulation indices

\begin{tabular}{|c|c|c|c|c|c|c|c|c|c|}
\hline \multirow[t]{2}{*}{ Artery } & \multicolumn{3}{|c|}{ Measured } & \multicolumn{3}{|c|}{ Modeled } & \multicolumn{3}{|c|}{$\begin{array}{l}\text { Inadequancy } \\
\%\end{array}$} \\
\hline & PI & RI & $\mathrm{S} / \mathrm{D}$ & PI & RI & $\mathrm{S} / \mathrm{D}$ & PI & RI & $\begin{array}{l}\text { S/ } \\
\text { D }\end{array}$ \\
\hline $\begin{array}{l}\text { Left } \\
\text { common } \\
\text { carotid }\end{array}$ & 2,65 & 0,89 & 9,43 & 1,89 & 0,8 & 7,63 & 29 & 10 & 19 \\
\hline $\begin{array}{l}\text { Left } \\
\text { brachial }\end{array}$ & 2,41 & 0,86 & 6,42 & 1,62 & 0,84 & 6,09 & 33 & 2 & 5 \\
\hline $\begin{array}{l}\text { Left } \\
\text { ulnar }\end{array}$ & 2,1 & 0,78 & 4,47 & 1,78 & 0,87 & 5,91 & 15 & 12 & 24 \\
\hline
\end{tabular}

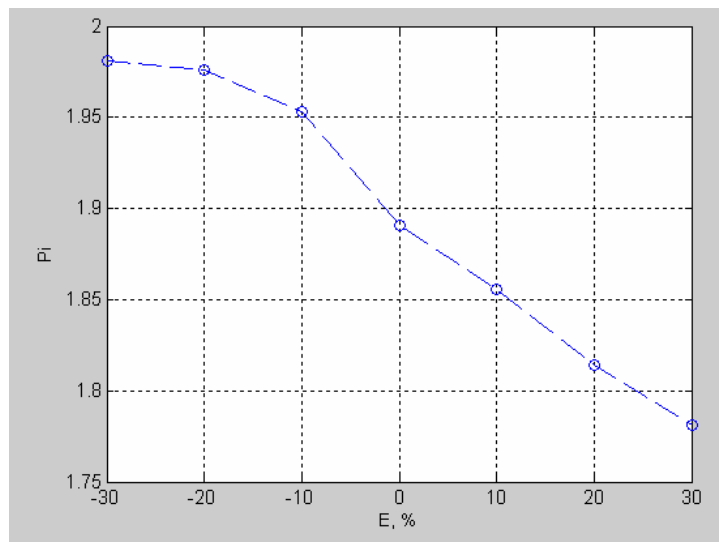

Fig. 7. Modeled PI and $E$ relationship for the left common carotid artery

\section{Discussion}

Proposed arterial tree model enables to acquire typical blood flow time functions in main peripheral arteries. Model adequacy was confirmed using noninvasive ultrasound doppler images. Mean inadequancy of the modeled and measured blood circulation indices $-17 \%$. This is quite good achievement considering that mean standard deviation is $9 \%$. One of the reasons for the inadequancy is the model assumptions taken into account, which simplifies complex and nonlinear blood circulation nature. Another important moment is the evaluation of the arteries properties. Mechanical and geometrical properties of the modeled arteries were indicated in literature and are only an approximate. Supposedly, arteries properties are varying for each individual depending on blood circulation characteristics. Thus the model should be carefully matched 
to an individual before certain medical diagnostic outcomes acquired.

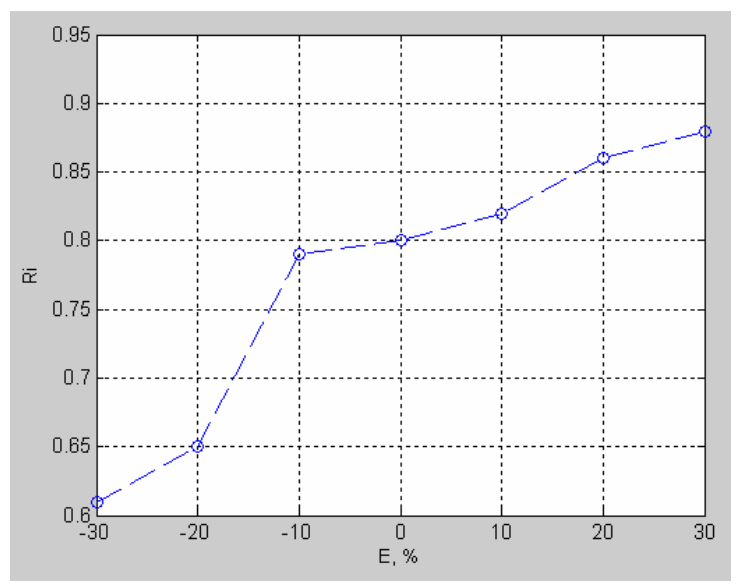

Fig. 8. Modeled RI and $\mathbf{E}$ relationship for the left common carotid artery

Model parameters are related to three important circulation factors, i.e. blood inertance, hemodynamic resistance and compliance of the arteries. The latter can be expressed using mechanical and geometrical artery properties, i.e. radius, wall thickness and elastic modulus. Thus after the model matching and adequancy confirmation, there is a possibility to evaluate the relevant mechanical index - elastic modulus. Modeling results showed, that decrease of the elasticity of the arteries, results in decrease of PI and vice versa. Also we observe inverse relationship of the elastic modulus and RI. It is obvious that PI indicates blood flow fluctuation (pulsation) in a heart beat. RI on the other hand, reveals resistance to the blood flow. Hence modeled relationships indicate increase of the blood flow pulsation and decrease of the resistance resulted from the increased elasticity of the arteries and vice versa.

\section{References}

1. Tekorius T., Ragulskis L., Kopustinskas A. Pulsacijos indekso tyrimas panaudojant kraujagyslès modeli. Elektronika ir elektrotechnika. 1997. No. 1. P. 23-25.

2. Oshima M., Torri R., Kobayashi N. Finite element simulation of blood flow in cerebral artery. Comput. Methods appl. Mech. Engrg. 2001. Vol. 191. P. 661-671.

3. Ferreira A. S., Barbora J. F., Souza M. N. Comparison of segmental arterial compliance determined with three and four element windkessel models. Proceedings of the 25 th. annual internat. conference of the IEEE EMBS. 2003. P. 3161-3164.

4. Li J. K-J. Arterial circulation: physical principles and clinical applications. New Jersey. 2000. P. 271.

5. Black J. Handbook of biomaterial properties. London. 1998. P. 590.

6. Kopustinskas A., Kupciunas I, Marcinkevicienè J. Estimation of arterial nonlinear compliance using ultrasound images. Electronics and Electrical Engineering. Kaunas: Technologija. 2010. Nr. 9(105). P. 9396.

7. Kopustinskas A., Kopustinskienė G. Application of ultrasound Doppler technique for blood flow evaluation. Ultragarsas. 2004. No.3(52).

I. Kupčiūnas, A. Kopustinskas

Paskirstytųjų parametrų arterijų medžio modeliavimas naudojant ultragarsinius D vaizdus

Reziumè

Nagrinejjamos galimybès naudoti ultragarsinius doplerinius vaizdus arterijų medžiui modeliuoti. Tam tikslui pasiūlytas paskirstytujų parametru arterijų medžio modelis, pagrịstas tiesinès perdavimo linijos lygtimis. Modeli sudaro 40 arterijų medžio segmentų, kurių kiekvienas pagal elektrohemodinaminès analogijos principą sudarytas iš R, L ir C elementu. Pritaikytos ORCAD ir MATLAB programinès irangos arteriju medžiui modeliuoti ir sonogramos vaizdas apdoroti. Ultragarsiniai kraujo greičio laiko funkcijos matavimai in vivo atlikti trijuose būdinguose arterijų medžio taškuose. Vidutinis $17 \%$ modelio adekvatumas gautas palyginus modeliavimo ir matavimo rezultatus. Ištirta arterijų mechaninių charakteristiku itaka kraujo srauto diagnostiniams parametrams. Nustatyta, kad didejjant kraujagyslès sienelès elastiniam moduliui pulsacijos indeksas dideja, o varžinis indeksas mažèja. Tyrimų rezultatai gali būti panaudoti arterijų standumo pakitimų diagnostikai atlikti.

Submitted 8062011 